\title{
Pharmacological and dietary prevention for colorectal cancer
}

\author{
Francesca Nolfo ${ }^{1}$, Stefania Rametta', Stefano Marventano ${ }^{1}$, Giuseppe Grosso ${ }^{2}$, Antonio Mistretta $^{1 *}$, Filippo Drago ${ }^{3}$, \\ Santi Gangi ${ }^{4}$, Francesco Basile ${ }^{4}$, Antonio Biondi ${ }^{4}$ \\ From 26th National Congress of the Italian Society of Geriatric Surgery \\ Naples, Italy. 19-22 June 2013
}

\begin{abstract}
Background: Colorectal cancer (CRC) is a leading cause of cancer morbidity and mortality. People at higher risk are those individuals with a family history of CRC and familial adenomatous polyposis. Prevention and screening are two milestones for this disease. The aim of this study is to evaluate the chemopreventive role of non-steroidal anti-inflammatory drugs (NSAIDs), including aspirin and cyclooxygenase 2 inhibitors, some micronutrients (folic acid, calcium, selenium, antioxidants) and probiotics.

Discussion: The studies on aspiring reported promising results, but it is debatable whether aspirin should be used as chemoprevention, because of its side effects and because of poor efficacy evident in subjects at high risk. Similar results were reported for other non-aspirin NSAIDs, such as sulindac and celecoxib, which the potential adverse effects limit their use. Selenium role in prevention of various types of cancer as well as in colon adenomas are often inconclusive or controversial. Several studies suggested that calcium may have a possible chemopreventive effect on colon adenomas and CRC, although contrasting results are reported for the latter. A recent meta-analysis including 13 randomized trial suggested that folic acid supplementation had not a chemiopreventive action on CRC. Several studies investigated the association between antioxidants, administered alone or in combination, and CRC risk, both among general and at risk population, but only few of them supported statistically significant results.

Conclusion: The results of this literature review showed an unclear role in CRC prevention of both pharmacological and dietary intervention. Despite several options are available to prevent colon cancer, it is challenging to identify a correct strategy to prevent CRC through pharmacological and dietary intervention due to the long latency of cancer promotion and development. Since some of the drugs investigated may have uncertain individual effects, it can be suggested to potentiate such effects by adding them together.
\end{abstract}

\section{Background}

During last decades, several progresses have been done in cancer prevention [1]. The introduction of the laparoscopic approach allowed a less invasive surgical therapy (as tertiary prevention) for colorectal cancer (CRC) patients [2-6]. Regarding the secondary prevention, the screening programs demonstrated high value in certain types of cancer, but only allow preventing progression

\footnotetext{
* Correspondence: anmistr@unict.it

'Department "G. F. Ingrassia" Section of Hygiene and Public Health,

University of Catania, Catania, Italy

Full list of author information is available at the end of the article
}

of already existing malignancies that often occur in elderly subjects $[7,8]$. Regarding CRC, which is the third most common cancer in males and the second in females [9], special attention has been paid to the adenomatous polyp or adenoma, which is an important surrogate endpoint for colon cancer [10]. The adenoma is a premalignant lesion, usually asymptomatic, which occurs generally among older individuals, especially those more than 50 years old [10]. It is common that colon cancers emerge from adenomas, although not all adenomas evolve in cancers $[10,11]$. However, since new adenomas often develop in individuals who have had previous adenomas 
that were ablated, a preventive intervention may focus on prevent formation of new adenomas as a surrogate marker of colon cancer.

Despite the recent development in drug therapy against CRC are promising $[12,13]$, primary prevention interventions against colorectal cancer mostly involve dietary measures, although a pharmacological approach demonstrated to be effective in selected subjects. Thus, the aim of this study is to review the effects of dietary and pharmacological experimental approach to identify chemopreventive agents and strategies against the CRC.

\section{Aspirin}

Acetylsalicylic acid (aspirin) is one of the most widely used drugs in the world [14]. Aspirin is a salicylate drug, nowadays mainly used as an analgesic to calm minor aches and pains, as an antipyretic to reduce fever, and as an anti-inflammatory medication. It also plays an important role in hypertension and in other cardiovascular diseases [15]. In fact, it has been long known that thanks to his antiplatelet effect by inhibiting the production of thromboxane, aspirin is used long-term, at low doses, to help prevent ischemic events [16]. The main undesirable side effects of aspirin assumption are gastrointestinal ulcers and stomach bleeding, especially in higher doses. Nausea and dyspepsia are milder adverse reactions, and fortunately the most frequent [17]. Because of his already mentioned antiplatelet effect, the use of aspirin in association with other drugs that increase the risk of bleeding must be controlled. In addition, aspirin should be used with prudence in the elderly, because of the risk of Reye's syndrome [18] and in individuals with favism, although recent studies have shown a good tolerance to low doses of the drug in these patients [19].

Despite aspirin at present is not a certified medicinal for cancer prevention, several lines of evidence propose that long-term use of aspirin might decrease the risk of some cancers, particularly gastrointestinal tumors [20]. Different researches have observed an inverse association between continuous aspirin intake and risk of CRC [21-23]. In 1991, Thun et al. [24] recruited 662,424 patients, proving a reduced risk of CRC mortality over a 6-year period, thanks to aspirin use at least 16 times per month. Similar findings were observed in subsequent studies, such as the Health Professionals Follow-up Study (HPFS) and the US Nurses' Health Study (NHS) cohort, which talked about an hazard reduction respectively equal to $21 \%$ in a cohort of men and $23 \%$ in a cohort of women only $[25,26]$. Two American $[27,28]$ and two European randomized studies [29,30] compared aspirin against a placebo group in the intermediate risk population, consisting of patients with history of adenomas. Sandler et al. [27] showed that daily aspirin intake for one year reduced by approximately $35 \%$ the risk of adenoma, of both the number and the rapidity of growth, in patients who had previously undergone surgical resection of colorectal cancer. The other study conducted in USA was a randomized, double-blind, placebo-controlled trial about the efficacy of different doses of oral aspirin, comparing $81 \mathrm{mg}$ and $325 \mathrm{mg}$ of aspirin per day with placebo in patients with a recent history of adenoma and finding that the relative risk (RR) of adenoma reappearance was lower in the $81 \mathrm{mg}$ group than in the $325 \mathrm{mg}$ one [28]. The same result about the effectiveness of aspirin in lowering the recurrence of colorectal adenomas in intermediated risk population has been demonstrated by Logan et al. [29], which also underlined a possible role of the drug in preventing the development of advanced lesions. In this 3-year study, folic acid was prescribed in addiction to aspirin to half of the patients in both the treated and the control group, but the evidence showed no protective efficacy conferred by this other medicine. Finally, in a study of 238 patients, with a history of adenoma, randomized to receive placebo, $160 \mathrm{mg}$ aspirin, or $300 \mathrm{mg}$ aspirin, the RR of adenoma recurrence was 0.61 in the $300 \mathrm{mg}$ group, and 0.85 in the $160 \mathrm{mg}$ group [30]. Besides, the RR for recurrent adenomas for the 300-mg group versus the $160 \mathrm{mg}$ group was 0.72 .

Although these promising result, it is debatable whether aspirin should be used as chemoprevention, because of its side effects and because of poor efficacy evident in subjects at high risk. Some studies specifically investigated the association between the use of aspirin and the risk of intestinal neoplasms among high risk population, such as patients with hereditary conditions with a known genetic basis, for instance adults with Lynch syndrome) [31] and people with familial adenomatous polyposis (FAP) [32]. Both studies compared aspirin (600 mg daily), with or without resistant starch (30 g daily), to resistant starch alone or placebo, demonstrating no benefits in reducing polyp number or the incidence of colorectal cancer. Nevertheless, the Colorectal Adenoma/carcinoma Prevention Program 1 (CAPP1) study founded a significant decline in polyp size among patients with FAP treated with aspirin for more than 1 year [32]. A probable different mismatch-repair-dependent neoplastic pathway, characterized by low susceptibility to protection from aspirin, may explain the absent efficacy of this drug in high-risk patients compared with those at intermediate risk [31]. Finally, several researches that analyzed the effect of aspirin on adenomas and CRC in low-risk populations have found that alternate day use of low-dose aspirin for an average 10 or 5 years of treatment did not lower CRC risk [33,34]. Other authors, instead, studied the effects of daily administered high dose of aspirin (300-500 mg/day for 1-7 years and 300-1500 mg/day for 5-6 years) but still no inverse relationship between aspirin use and risk of 
adenomas or CRC was found [35,36]. On the other hand, an updated analysis of these cohorts made by Flossmann et al. [37], observed that over a follow-up period of up to 23 years there was a statistically significant $26 \%$ reduction in the relative risk of CRC incidence in aspirin users versus nonusers.

Regarding the possible mechanism of action of aspirin in preventing oncological diseases, it may depends on its most well-known pharmacologic effect such as the permanent modification of the COX enzymes, which are responsible for the conversion of arachidonic acid to prostaglandins, relating eicosanoids. Cyclo-oxygenase- 1 is in many tissues, while the isoenzyme 2 of COX is almost undetectable in normal tissue and produces prostaglandins for inflammatory response. COX-2 is up-regulated in many cancers such as CRC but also in colorectal adenomas $[38,39]$. In fact, as suggested by different studies COX-2 may play a role in colorectal tumor growth and development, by its effect on pro- and anti-inflammatory cytokines, migration, apoptosis transcription, and angiogenic factors $[40,41]$. It seems that the chemopreventive effect, still unclear, of aspirin against CRC is due to the COX-2 inhibitory action both directly, by suppressing prostanoids release, and indirectly, through its effects on platelets [38]. In fact, aspirin mediated inhibition of platelets may block the liberation of mediators that promote COX-2 expression in nucleated cells at sites of mucosal injury [39]. There are also some nonCOX-related pathways that may explain aspirin's antineoplastic effects, such as the promotion of apoptosis in cancer cells [42], the diminution of microsatellite instability in CRC cells [43], the modulation of expression of transcription factors induced by oncogenes and the induction of spermidine/spermine N1-acetyltransferase, which results in modulation of polyamine synthesis, essential for neoplastic cell growth $[44,45]$.

\section{Non-aspirin non-steroidal anti-inflammatory drugs (NSAIDs)}

Study on chemoprevention of CRC and/or adenomatous polyps in populations at differing risks investigated the role of NSAIDs, including aspirin and cyclo-oxygenase- 2 (COX-2) inhibitors. The only drug authorized for this purpose by the European Medicines Agency is the Celecoxib a non-aspirin NSAIDs selectively blocker COX-2. It was demonstrated to be effective in reducing the number of polyps in patients with familial adenomatous polyposis (FAP) and it is also used in addition to surgery and endoscopic surveillance [46]. Many controlled trials have been made in different countries to investigate NSAIDs efficacy and safety in adenomas and cancer chemoprevention. A randomized, double-blind, placebocontrolled study on 41 young subjects (8-25 years) genotypically, but not phenotypically, affected with FAP were treated with sulindac or placebo for 48 months. The results showed that standard doses of sulindac (75 or $150 \mathrm{mg}$ twice a day) did not prevent the development of adenomas in subjects with FAP [47]. A previous trial conducted on 22 patients with FAP receiving sulindac at the dose of $150 \mathrm{mg}$ orally twice a day for nine months showed a reduction in numbers and size of colorectal adenomas. However, after one year of follow-up, this treatment demonstrated only a partial efficacy, and cannot replace colectomy as primary therapy [48]. Nugent et al. [49] conducted a randomized trial on 24 patients with FAP and advanced duodenal polyposis who had previously undergone prophylactic colectomy. Patients received sulindac at the dose of $400 \mathrm{mg}$ once a day for six months. At the end of the treatment period a significant regression both in duodenal and rectal polyps was found.

The effectiveness of sulindac in inducing the regression of rectal polyps in FAP was also demonstrated by another double-blind trial conducted on 10 patients with rectal polyps and previously treated by colectomy and ileorectal anastomosis [50]. Patients received sulindac (300 mg/day) or placebo during two 4-month periods separated by a 1-month washout phase. The authors observed significant differences in complete and almost complete regression between the sulinac and the placebo groups. Other placebo-controlled, double-blind trials, showed a significant regression of colorectal adenomas in patients with FAP using $400 \mathrm{mg}$ of celecoxib twice daily [51] and a significantly reduction of recurrence of colorectal adenomas within three years after polypectomy using $400 \mathrm{mg}$ of celecoxib once daily [52]. On the contrary, another study showed that the inhibition of a COX-2 with a 150-200 mg dose of a selective COX-2 inhibitor did not induce clinically sufficient regression of adenomas in patients with FAP in a limited (6-month) medication period [53].

Despite the positive results of the use of NSAIDs in chemoprevention of CRC, the potential adverse effects limit their use. Results from a trial conducted on 2.035 subjects that received $200 \mathrm{mg}$ or $400 \mathrm{mg}$ of calecoxib twice daily for 3 years, found a reduction in the incidence of colorectal adenomas, compared with the placebo one, but also an increased risk of cardiovascular events. The RR was 2.6 (95\% CI 1.1-1.6) and 3.4 (95\% CI 1.5-7.9) for low and high dose respectively [54]. These results are in according with a recent doubleblind trial on 1561 subjects with removed colorectal adenomas followed for 5 years. At the end of the follow up the incidence of new and advanced adenomas were significantly lower in the celecoxib group than in the placebo group, however renal/hypertension events (RR 1.35; 95\% CI 1.09-1.68) and cardiac disorders (RR 1.59; 95\% CI 1.12-2.26) were highter in the celecoxib group [55]. 
A more recent study focused on the effect of NSAIDs on various pro- and anti-inflammatory cytokines, transcription, and angiogenic factors that are involved in the promotion and growing of many cancers. The findings suggest that co-administration of Sulindac and Celecoxib significantly reduce the angiogenic potential of the growing neoplasm, but its consumption is not toxic free (serious adverse events to gastrointestinal, renal and cardiovascular systems have been reported) [56]. A possible solution for the adverse effect of NSAIDs used as treatment of FAP could be the administration of colon-specific delivery of these drugs. Lee et al. [57] has found that the use of colon-specific prodrug of celecoxib may be a useful strategy to reduce the toxic effect and improve the pharmacological properties of celecoxib.

\section{Selenium}

Selenium is an essential micronutrient present in nature implicated in numerous biological functions, such as a protective effect against oxidative damage of cells, formation of thyroid hormones and modulation of immune system $[58,59]$. Most of the selenium in the body comes from diet. The aliments richest in selenium are liver, fish, poultry and wheat. The recommended daily intake of selenium varies from $60 \mu \mathrm{g} /$ day for women, to $70 \mu \mathrm{g} /$ day for men [59]. Selenium role in prevention of various types of cancer as well as in colon adenomas are often inconclusive or controversial. An experimental study attributed the potential preventive action of selenium to its role in the acceleration of DNA repair and in the reduction of DNA damage, with a decrease in number of mutations that ultimately contribute to carcinogenesis [60]. Another possible mechanisms involved could be the induction of apoptosis through the activation of caspase3 and the modulation of glutathione and mitochondrial functions [61].

Clark et al. [62] in a multicenter, double-blind, randomized, placebo-controlled cancer prevention trial conducted on 1312 subject with a history of basal cell or squamous cell carcinomas of the skin (receiving $200 \mu \mathrm{g}$ of selenium or placebo per day) showed that the daily administration of selenium had no protective effect against the development of skin cancer. Nevertheless, a significant reductions in total cancer mortality in selenium treatment group (RR 0.50; 95\% CI 0.31-0.80) and in total cancer incidence (RR 0.63; 95\% CI 0.47-0.85) was found. Conversely other studies didn't found a protective role of selenium in cancer [63-65].

A meta-analysis on antioxidant supplements for prevention of gastrointestinal cancers confirmed the no role of selenium in cancer prevention with a RR of 0.48 (95\% CI 0.22-1.05) [66]. However in four of the fourteen trials evaluated, selenium showed significant beneficial effect on the incidence of gastrointestinal cancer (RR
0.50; 95\% CI 0.35-0.71). The authors pointed out that this result might be biased because of low methodological quality in three of four trials.

On the preventive effect of colorectal adenoma selenium showed a significant effect in specific group of subject. An inverse association between serum selenium and advanced colorectal adenoma was found in current smoker (OR 0.27; 95\% CI 0.11-0.66) and in subject with the lowest tertile of baseline selenium (OR 0.27; 95\% CI $0.09-0.77$ ) [67]. These results are also confirmed by another randomized trial on 758 cases and 767 sex- and race-matched controls, where an OR of 0.63 (95\% CI 0.47-0.84) and 0.44 (95\% CI 0.24-0.81) were found for the lowest quintile of baseline selenium and current smokers, respectively [68]. Finally a more recent doubleblind randomized trial conducted on 411 patients who had undergone a polypectomy, showing that the coadministration of selenium with other antioxidants significantly reduced the risk of adenoma recurrence in these patients (HR 0.61; 95 \% CI 0.41-0.92) [69].

\section{Calcium}

Calcium is essential for living organisms being involved in biological processes and being one of the main components of bones, teeth and nails. It is not currently a recognized chemopreventive agent for colon cancer but its intake is recommended in cases of deficient such as osteoporosis or in older adults. The use must be controlled and limited in cases of kidney failure, sarcoidosis or nephrolithiasis and its administration is contraindicated in the patients with hypercalcaemia and hypercalciuria. In case of excess can cause gastrointestinal disturbances, bradycardia and arrhythmias [70].

The mechanisms of action of calcium implicated in the inhibition of colorectal carcinogenesis include the control of cell proliferation, differentiation, and apoptosis. Numerous input signals and intracellular pathways are responsive to calcium and the response of a cell is strictly contextual and linked to the cell type [71]. The modulation of calcium-sensing receptors with the following cascade of intracellular events and the direct role as activator/cofactor in protein kinase $\mathrm{C}$ activation are only two of the essential role of calcium in the cell growth and differentiation. Furthermore calcium is also involved in the transcription process through the direct influence of CREB (cAMP response element-binding protein) [72]. In particular, colonocytes respond to calcium exposure with the acquisition of a differentiated phenotype and their sensibility to calcium remain until the disruption of the calcium signaling differentiation-inducing network by the neoplastic process [73]. There is also some evidence on normal and transformed colonic cells of the direct antiproliferative, differentiation and apoptosis-inducing action of calcium $[74,75]$. 
Several studies suggested that calcium may have a possible chemopreventive effect on colon adenomas and CRC. A recent analysis conducted on 1.235 subjects (420 with CRC and 815 controls) investigated the dietary calcium intake and its possible interactions with calcium-sensing receptor (CASR) gene polymorphisms on colorectal cancer risk. A food frequency questionnaire and single nucleotide polymorphisms (SNPs) of CASR research were performed and in all of the polymorphisms examined a significant higher odds ratios was found in the low-calcium-intake group compared to the high-calcium-intake group [76]. In subject with a history of adenoma many randomize trial found a slightly effect of calcium. Thomas et al. [77] showed that calcium reduces colorectal cell turnover but no effect on the number, size or distribution of rectal polyps in a double-blind study carried out on 25 patients with FAP receiving supplemental calcium carbonate (1.5 g/day) or placebo tablets for 6 months. Another study, performed on patients that received calcium gluconolactate and carbonate ( 2 g elemental calcium daily) or placebo for 3 years, showed a modest but not significant reduction in the risk of adenoma recurrence (OR $0.6695 \%$ CI 0.38-1.17) [78] On the contrary, a trial performed on 930 subject receiving $1.2 \mathrm{~g}$ of elementary calcium daily for 4 years, showed that the calcium group, compared with the placebo one, had a lower risk to have at least one adenoma (OR 0.81; 95\% CI 0.67-0.99) and also in the average number of adenomas (OR 0.76; 95\% CI 0.60 to 0.96) [79]. In a prospective intervention study, 116 polyp-bearing patients received $1.6 \mathrm{~g} /$ day of calcium combined with some antioxidants (beta-carotene, vitamin E, vitamin C, selenium) were followed for 3 years. At 3 years no differences were found on polyp growth between the intervention and the placebo group. However a significant reduction in the number of new adenomas was found, suggesting a possible protective role of calcium in the formation of new adenomas [80]. A most recent study assessing the predictive value of CRC risk factors for the detection of advanced colorectal adenoma on 1236 randomly selected subject, confirmed that calcium intake could have a small protective effect (OR 0.99 per mg; $95 \%$ CI 0.99-1.00) [81].

Regarding the CRC, a published meta-analysis on sixteen trials investigated the effect of calcium supplements without co-administered vitamin D on cancer risk finding that calcium did not alter the risk of colorectal cancer (RR 1.38; 95\% CI 0.89-2.15) [82]. Conversely, another study on 85,903 men and 105,108 women examined the associations of intakes of calcium and vitamin $\mathrm{D}$ with CRC risk reporting an inverse association with CRC both for calcium intake [men (RR 0.70; 95\% CI 0.52-0.93; p for trend <0.05); woman (RR 0.64; 95\% CI 0.50-0.83; p for trend <0.05)] and dairy products [men (RR 0.77; 95\% CI 0.59-1.01; p for trend <0.05); women (RR 0.66; 95\% CI 0.49- 0.89; p for trend <0.05) [83]. As the previous study, other authors investigated the associations between the consumption of dairy foods and calcium with cancer risk. One of these studies conducted on 36,965 men and 16,605 women cancer cases failed in found a linear association between calcium intake and cancer [84]. However dairy food and calcium intakes were significantly associated with digestive system cancer (RR 0.84; 95\% CI 0.77-0.92 in men, and RR 0.77; 95\% CI 0.69-0.91 in women) and particularly with $\mathrm{CRC}$ both in men and women. Cho et al. [85] analyzed a pool of 10 cohort studies included 534,536 individuals, among whom 4,992 incident cases of colorectal cancer. Compared with the lowest intake category of milk, dietary calcium and total calcium the RR for the highest category were 0.85 (95\% CI 0.78-0.94; p for trend $<0.05$ ), 0.86 (95\% CI 0.78-0.95; p for trend <0.05) and $0.78(95 \%$ CI 0.69- 0.88; p for trend $<0.001$ ), respectively. These results are also confirmed by a meta-analysis conducted to evaluate the relationship between the consumption of dairy products, calcium, vitamin $\mathrm{D}$ and the inhibition of the development of CRC [86]. Data from 60 epidemiological studies enrolling 26.335 CRC cases were analyzed. High milk and dairy product intake RR on colon cancer risk were, respectively, 0.78 (95\% CI 0.67-0.92) and 0.84 (95\% CI 0.75-0.95). Furthermore a high calcium intake was found to reduce CRC risk.

Other studies investigated the role of calcium or calcium plus vitamin D in CRC prevention focusing their research on population subgroups. The trial reported by Lappe et al. [87] was conducted on 1,179 postmenopausal women divided in three groups: calcium alone (1.4-1.5 g/day), calcium (1.4-1.5 g/day) plus vitamin D (1100 IU) and placebo. The treatment period was four years as well as the follow up period. The results showed that calcium plus vitamin D (RR 0.40; 95\% CI 0.20-0.82) but not calcium alone (RR 0.53; 95\% CI 0.27-1.03) reduce all-cancer risk in these subject. On contrary the Wactawski et al. [88] study performed on 36,282 postmenopausal women received calcium $1 \mathrm{~g}$ /day plus vitamin D $400 \mathrm{IU} /$ day or placebo for 7 years found no significant effect of daily supplementation of calcium with vitamin D on colorectal cancer incidence. Another study on women with a prospective cohort of 45,354 subjects without a history of colorectal cancer followed for 8.5 years found an approximately $25 \%$ reductions CRC risk for both high dietary and supplement calcium intake [89]. Moreover a mayor protective effect was showed for the simultaneously high consumption of calcium, both for dietary and supplement (RR 0.54; 95\% CI 0.37-0.79).

\section{Folic acid}

Folic acid is a water-soluble B vitamin needed for all the reactions of synthesis, repair and methylation of DNA, 
homocysteine metabolism (methylation) and other important biochemical reactions [90]. Humans cannot synthesize folate de novo and the recommended dietary intake change with age, sex or other conditions such as pregnancy or lactation. Therapy with folic acid supplement is indicated in pregnancy to reduce the risk of anemia and to prevent the occurrence of neural tube defects in the fetus [91]. It is also indicated, in combination with vitamin B12, in cases of megaloblastic anemia caused by insufficient dietary intake, and also for the anemia prophylaxis in chronic haemolytic states, malabsorption, or in renal dialysis. Important adverse effects due to folic acid supplementation are very rare, except for some gastrointestinal disorder.

A diet low in folate could be implicated in the onset of many cancers due to folic acid role in stability of DNA by regulating DNA biosynthesis, repair and methylation [92]. In fact, the altered DNA and RNA methylation, and the disruption of DNA integrity and repair, lead to DNA aberrations with a higher risk of developing cancers and in particularly the colorectal one [93]. Furthermore, the results of a randomized trial conducted on fourteen subjects with adenoma receiving $400 \mathrm{mcg} /$ day or placebo for 10 weeks, indicated that folic acid can modify gene expression [94].

The association between diminished folate status or folate supplement and colorectal carcinogenesis had been investigated in many studies. Baron et al. [95] to study the protective effect of fruits and vegetables against the risk of CRC administered a food-frequency questionnaire to patients with adenoma, at baseline and four years later. The obtained results showed a protective effect of folic acid against CRC, however after adjustment for intake of dietary fiber and fat, folate supplements was not associated with a reduction in CRC risk. Furthermore the alcohol intake that can reduce circulating folate levels and interfere with some of its biochemical actions was investigated. Findings reported a significant association between alcohol intake and increased risk of adenoma recurrence (OR 2.04; 95\% CI 1.28-3.26) both for man and woman. Similarly another study showed the same results for high alcohol intake, but found more consistent results on the protective effect of high dietary folate, in women RR 0.66 (95\% CI 0.46-0.95) and men RR 0.63 (95\% CI 0.41-0.98) [96]. On the contrary, a randomized study on women with high risk of cardiovascular disease, receiving folic acid $2.5 \mathrm{mg} /$ day, vitamin $\mathrm{B} 650 \mathrm{mg} /$ day and vitamin B12 $1 \mathrm{mg} /$ day or placebo for 7 years, showed that the combined intake of these components did not have a significant effect on the risk of cancer occurrence ( HR 0.97; 95\% CI 0.79-1.18) [97].

In a double-blind, placebo-controlled trial on 137 subjects with adenomatous polyps, patients received $5 \mathrm{mg} /$ day of folic acid for 3 years showed a significant reduction in the recurrence of colonic adenomas compared to the placebo group [98]. Another trial conducted on 216 patients with atrophic gastritis receiving different combination of folic acid and beta-carotene, demonstrated a lower risk of gastrointestinal cancers in the folic acid group (OR 0.12; 95\% CI 0.03-0.51) [99]. Different findings were found by Logan et al. [29] in a multicenter, randomized, doubleblind trial on 945 adenoma patients, in which a supplementation of $0.5 \mathrm{mg} /$ day of folic acid for 3 years showed no effect on adenoma recurrence (RR 1.07; 95\% CI 0.851.34). The same result were showed by a double blind placebo controlled trial conducted on patients with a recent history of colorectal adenomas who received folic acid (1 mg/day) with or without aspirin (81-325 mg/day) for three years. Both at three and five years follow up folic acid was not found to reduce colorectal adenomas [100]. Finally, a recent meta-analysis including 13 randomized trial confirmed these findings, suggesting that folic acid supplementation had not a chemiopreventive action on CRC (RR 1.01; 95\% CI 0.82-1.23) [101].

\section{Probiotics}

According to the official definition of FAO and WHO, probiotics are "live organisms which, when administered in adequate amounts, bring benefit to the health of the host" [102]. The mechanisms by which probiotics may inhibit colon cancer are not yet fully understood. However, there is evidence for a reduction in the inflammatory response to host flora, alterations in the metabolic activities of intestinal bacteria, a reduction in the numbers of bacteria involved in pro-carcinogenic and mutagenic pathways, and the production of anti-tumorigenic and mutagenic substances [103]. In an experimental study, Ma et al. [104] showed that the probiotic Bacillus polyfermenticus, through the reduction of ErbB2 and ErbB3 receptors (known to have essential roles in tumor development), suppressed colon cancer cells growth both in vitro and in vivo. Another study conducted on animal models showed that the intake of probiotics is associated with anticarcinogenic effects, due to the reduction of genotoxic agents in the intestine and, concurrently to the rice in the production of agents that deactivate these toxic components [105]. Rafter et al. [106] conducted a study on 37 colon cancer patients and 43 polypectomized patients that received a synbiotic food composed of prebiotic and probiotics or placebo for twelve weeks. Results showed that the intake of this compound led to positive changes in the bacterial flora and reduced the colorectal proliferation in adenoma patient, but no in the cancer one. Similar results on microflora changes were found in a double bind, placebo controlled study conducted on 20 subjects received resistant starch or Bifidobacterium lactis, either alone or 
as a combined symbiotic preparation for four weeks. However, no significantly variation on epithelial proliferation was observed [107].

Although many studies investigated the role of probiotics, there is still no clear clinical evidence of the protective role of probiotics in CRC. Further research is needed to establish the real usefulness of probiotics in CRC prevention [108].

\section{Antioxidants}

Antioxidants have been universally studied for prevention of chronic disease, including inflammation, atherosclerosis, neurodegenerative diseases, and also cancer [109-111]. A body of evidence suggests that oxidative stress and the consequent peroxidation of lipid are involved in these pathological states. Antioxidants, such as various vitamins, may be introduced by "eating good", this means following a diet high in fruits and vegetables or as dietary supplements. In fact it was seen that intake of this kind of foods decrease the risk of developing cancer and cardiovascular disease [112].

Vitamins may be prescribed to prevent or treat their corresponding deficit. Lack of vitamin $\mathrm{C}$ is a very rare eventuality among people who eat a balanced diet. When it occurs, it causes scurvy, which can lead to death if not treated [109]. Also vitamin A (retinol) deficiency is uncommon and it is correlated with ocular problems, such as night blindness or xerophthalmia, and immune system disorders. On the other hand, excessive doses of the vitamin may be toxic, causing, among other things, birth defects. Thus, retinol additions are contraindicated specifically in pregnant women. Some studies reported the necessity of vitamin E intake in adulthood, especially if a possible cholestasis causes fats malabsorption. It seems that this medicament could play a role in the treatment of thromboembolic disease even if its use should be done with prudent. As the previous one, an excess of vitamin $\mathrm{E}(>1 \mathrm{~g} /$ day) can produce side effects, such as diarrhea and abdominal pain [113]. Finally, another important antioxidant is vitamin $\mathrm{D}$, which consists of ergocalciferol, or vitamin D2, colecalciferol, also known as vitamin D3, dihydrotachysterol, alfacalcidol and calcitriol. Vitamin D2 is present in plants and some fish, so that its deficiency results from a low dietary intake. Vitamin D3 is produced in the skin by way of ultraviolet B rays, thus a low exposure to sunlight can cause its deficiency [114]. Several studies suggest that combined calcium and vitamin D supplementation, but not limited to vitamin $\mathrm{D}$, prevented bone loss and it is recommended to prevent and treat osteoporosis and in elderly patients [115]. Some observational studies in humans and animal models support that vitamin D has a favorable role in cancer prevention, probably due to its action in the regulation of cell growth and differentiation [116].
Focusing on CRC, observational analyses have found an inverse correlation between calcium and vitamin D intake and risk of CRC [78] and recurrent polyps [80].

Thomas et al. [77], considering a high-risk population made by patients with familial adenomatous polyposis (FAP) who had previously undergone total abdominal colectomy with ileorectal anastomosis, observed that calcium had no evident effect on the number, volume or distribution of rectal polyps. Instead, there are no studies about the relationship between antioxidant and colorectal cancer risk in high risk group.

Considering people with previously adenomas or CRC, it has been compared antioxidants, alone or in combination, against placebo. For example, Greenberg et al. [117] selected 864 patients with an history of adenoma removed from large bowel, and dividing them into different treatment groups, administered placebo, beta carotene ( $25 \mathrm{mg}$ daily), vitamin C (1 g daily) and vitamin $\mathrm{E}$ (400 mg daily), or beta carotene plus vitamins $C$ and $E$. The result of this investigation has demonstrated a lack of chemopreventive action of antioxidants against CRC.

A Canadian study examined one hundred thirty-seven people to value the effects of vitamins $C$ and $E$ against placebo on the rate of recurrence of colorectal polyps, but the correlation found is small and may be attributed to chance (relative risk of 0.86) [118]. A combination of vitamin $\mathrm{A}, \mathrm{C}$ and $\mathrm{E}$ or lactulose were used to evaluate their chemopreventive attitude against the reappearance of colorectal polyps after their endoscopic removal, with positive results. In fact, polyps recurred in $5.7 \%$ of the individuals treated with vitamins, $14.7 \%$ of patients with lactulose and $35.9 \%$ of untreated controls [119]. Similar findings were obtained in an Italian work on 255 individuals after polipectomy [120].

MacLennan et al. [121] performed a randomized, partially double-blinded, placebo-controlled trial to estimate the efficacy on adenomas occurrence of lowering dietary fat to $25 \%$ of total calories and fortifying diet with $25 \mathrm{~g}$ of wheat bran daily and a capsule of beta carotene $(20 \mathrm{mg}$ daily). This found that there was no statistically significant prevention of new adenomas with any of the supplements, although persons who received combined intervention of low fat and added wheat bran developed no adenomas.

Several studies specifically investigated the association between antioxidants, administered alone or in combination, and CRC risk among general population $[63,99$, 122-131]. The average duration of treatment was about 7 years and the follow-up of participants ranged from 5 to 12 years. Among the 14 analyses executed, only few of them supported statistically significant results, such as the one made by Malila et al. [128]. In this work, participants, middle-aged male smokers, were randomly assigned to four supplementation groups: alpha-tocopherol (AT), $50 \mathrm{mg} /$ day; beta-carotene (BC), $20 \mathrm{mg} /$ day; both AT and 
$\mathrm{BC}$; and placebo. They found an increased CRC risk in the group with $\alpha$-tocopherol supplementation compared with the no- $\alpha$-tocopherol group. Instead $\beta$-carotene supplementation had no effect on the incidence of adenomas.

However, according to the results from previous reviews, there is no convincing evidence that antioxidant supplements play a significant beneficial role in preventing adenoma or gastrointestinal cancer, including CRC $[122,132,133]$.

\section{Conclusions}

The results of this literature review showed an unclear role in CRC prevention of both pharmacological and dietary intervention. Despite several options are available to prevent colon cancer, it is challenging to identify a correct strategy to prevent CRC through pharmacological and dietary intervention due to the long latency of cancer promotion and development. Since some of the drugs investigated may have uncertain individual effects, it can be suggested to potentiate such effects by adding them together.

\section{Competing interests}

The authors declare that they have no competing interests.

\section{Authors' contributions}

FN: conception and design, drafting the manuscript; SR, GG, AM, SM: drafting the manuscript; FD, FB, AB: critical revision, given final approval of the version to be published

\section{Acknowledgements}

Giuseppe Grosso was supported by the International Ph.D. Program in Neuropharmacology, University of Catania Medical School, Catania, Italy. The funders had no role in the study design, data collection and analysis, decision to publish, or preparation of the manuscript.

\section{Declarations}

Funding for this article came from University funds.

This article has been published as part of BMC Surgery Volume 13 Supplement 2, 2013: Proceedings from the 26th National Congress of the Italian Society of Geriatric Surgery. The full contents of the supplement are available online at http://www.biomedcentral.com/bmcsurg/supplements/13/S2

\section{Authors' details}

${ }^{1}$ Department "G. F. Ingrassia" Section of Hygiene and Public Health, University of Catania, Catania, Italy. ${ }^{2}$ Department of Drug Sciences, Section of Biochemistry, University of Catania, Catania, Italy. ${ }^{3}$ Department of Clinical and Molecular Biomedicine, Section of Pharmacology and Biochemistry, University of Catania, Catania, Italy. ${ }^{4}$ Department of General Surgery, Section of General Surgery and Oncology, University Medical School of Catania, Italy.

Published: 8 October 2013

\section{References}

1. Frieden TR, Myers JE, Krauskopf MS, Farley TA: A public health approach to winning the war against cancer. The oncologist 2008, 13(12):1306-1313.

2. Grosso G, Biondi A, Marventano S, Mistretta A, Calabrese G, Basile F: Major postoperative complications and survival for colon cancer elderly patients. BMC surgery 2012, 12(Suppl 1):S20

3. Biondi A, Grosso G, Mistretta A, Marventano S, Toscano C, Gruttadauria S, Basile F: Laparoscopic-assisted versus open surgery for colorectal cancer: short- and long-term outcomes comparison. Journal of laparoendoscopic \& advanced surgical techniques Part A 2013, 23(1):1-7.
4. Biondi A, Motta S, Di Giunta M, Crisafi RM, Zappala S, Rapisarda D, Basile F: [The use of laparoscopy for diagnosis and stadiation of the lymphomas] Annali italiani di chirurgia 2009, 80(6):445-447.

5. Biondi A, Tropea A, Basile F: Clinical rescue evaluation in laparoscopic surgery for hepatic metastases by colorectal cancer. Surgical laparoscopy, endoscopy \& percutaneous techniques 2010, 20(2):69-72.

6. Biondi A, Tropea A, Monaco G, Musumeci N, Benfatto G, Basile F: [Management of early rectal cancer: our clinical experience]. // Giornale di chirurgia 2011, 32(12):34-36.

7. Vacante M, D'Agata V, Motta M, Malaguarnera G, Biondi A, Basile F, Malaguarnera M, Gagliano C, Drago F, Salamone S: Centenarians and supercentenarians: a black swan. Emerging social, medical and surgical problems. BMC surgery 2012, 12(Suppl 1):S36.

8. Smith RA, Brooks D, Cokkinides V, Saslow D, Brawley OW: Cancer screening in the United States, 2013: a review of current American Cancer Society guidelines, current issues in cancer screening, and new guidance on cervical cancer screening and lung cancer screening. CA: a cancer journal for clinicians 2013, 63(2):88-105.

9. Jemal A, Bray F, Center MM, Ferlay J, Ward E, Forman D: Global cancer statistics. CA: a cancer journal for clinicians 2011, 61(2):69-90.

10. Rex DK, Ahnen DJ, Baron JA, Batts KP, Burke CA, Burt RW, Goldblum JR, Guillem JG, Kahi CJ, Kalady MF, et al: Serrated lesions of the colorectum: review and recommendations from an expert panel. The American journal of gastroenterology 2012, 107(9):1315-1329, quiz 1314, 1330.

11. Benfatto G, Biondi A, Di Stefano G, Basile G, Jiryis A, Strano G, Mugavero F, Cinardi N, Benfatto SM: Low rectal cancer treatment in frail elderly patients. A personal series. // Giornale di chirurgia 2007, 28(5):203-208.

12. Ragusa M, Statello L, Maugeri M, Majorana A, Barbagallo D, Salito L, Sammito M, Santonocito M, Angelica R, Cavallaro A, et al: Specific alterations of the microRNA transcriptome and global network structure in colorectal cancer after treatment with MAPK/ERK inhibitors. J Mol Med (Berl) 2012, 90(12):1421-1438

13. Ragusa M, Majorana A, Statello L, Maugeri M, Salito L, Barbagallo D, Guglielmino MR, Duro LR, Angelica R, Caltabiano R, et al: Specific alterations of microRNA transcriptome and global network structure in colorectal carcinoma after cetuximab treatment. Molecular cancer therapeutics 2010, 9(12):3396-3409.

14. Norn S, Permin H, Kruse PR, Kruse E: From willow bark to acetylsalicylic acid. Dansk medicinhistorisk arbog 2009, 37:79-98.

15. Lanas A, McCarthy D, Voelker M, Brueckner A, Senn S, Baron JA: Short-term acetylsalicylic acid (aspirin) use for pain, fever, or colds - gastrointestinal adverse effects: a meta-analysis of randomized clinical trials. Drugs in R\&D 2011, 11(3):277-288.

16. Lewis HD, Davis JW, Archibald DG, Steinke WE, Smitherman TC, Doherty JE, Schnaper HW, LeWinter MM, Linares E, Pouget JM, et al: Protective effects of aspirin against acute myocardial infarction and death in men with unstable angina. Results of a Veterans Administration Cooperative Study. The New England journal of medicine 1983, 309(7):396-403.

17. Dube C, Rostom A, Lewin G, Tsertsvadze A, Barrowman N, Code C, Sampson M, Moher D: The use of aspirin for primary prevention of colorectal cancer: a systematic review prepared for the U.S. Preventive Services Task Force. Annals of internal medicine 2007, 146(5):365-375.

18. Macdonald S: Aspirin use to be banned in under 16 year olds. BMJ 2002, 325(7371):988

19. Rigattieri S, Silvestri P, Minucci A, Di Russo C, Ferraiuolo G, Giardina B, Capoluongo E, Loschiavo P: Drug-eluting stents in a patient with favism: is the aspirin administration safe? J Cardiovasc Med (Hagerstown) 2008, 9(11):1159-1162.

20. Rothwell PM, Fowkes FG, Belch JF, Ogawa H, Warlow CP, Meade TW: Effect of daily aspirin on long-term risk of death due to cancer: analysis of individual patient data from randomised trials. Lancet 2011 377(9759):31-41

21. Thun MJ, Calle EE, Namboodiri MM, Flanders WD, Coates RJ, Byers T, Boffetta P, Garfinkel L, Heath CW Jr: Risk factors for fatal colon cancer in a large prospective study. Journal of the National Cancer Institute 1992, 84(19):1491-1500.

22. Neugut Al, Jacobson JS, De Vivo I: Epidemiology of colorectal adenomatous polyps. Cancer epidemiology, biomarkers \& prevention : a publication of the American Association for Cancer Research, cosponsored by the American Society of Preventive Oncology 1993, 2(2):159-176. 
23. Arber N: Do NSAIDs prevent colorectal cancer? Canadian journal of gastroenterology = Journal canadien de gastroenterologie 2000, 14(4):299-307.

24. Thun MJ, Namboodiri MM, Heath CW Jr: Aspirin use and reduced risk of fatal colon cancer. The New England journal of medicine 1991, 325(23):1593-1596.

25. Chan AT, Giovannucci EL, Meyerhardt JA, Schernhammer ES, Wu K, Fuchs CS: Aspirin dose and duration of use and risk of colorectal cancer in men. Gastroenterology 2008, 134(1):21-28.

26. Chan AT, Giovannucci EL, Meyerhardt JA, Schernhammer ES, Curhan GC, Fuchs CS: Long-term use of aspirin and nonsteroidal anti-inflammatory drugs and risk of colorectal cancer. JAMA : the journal of the American Medical Association 2005, 294(8):914-923.

27. Sandler RS, Halabi S, Baron JA, Budinger S, Paskett E, Keresztes R, Petrelli N, Pipas JM, Karp DD, Loprinzi $C L$, et al: A randomized trial of aspirin to prevent colorectal adenomas in patients with previous colorectal cancer. The New England journal of medicine 2003, 348(10):883-890.

28. Baron JA, Cole BF, Sandler RS, Haile RW, Ahnen D, Bresalier R, McKeownEyssen $G$, Summers RW, Rothstein $R$, Burke $C A$, et al: A randomized trial of aspirin to prevent colorectal adenomas. The New England journal of medicine 2003, 348(10):891-899.

29. Logan RF, Grainge MJ, Shepherd VC, Armitage NC, Muir KR: Aspirin and folic acid for the prevention of recurrent colorectal adenomas. Gastroenterology 2008, 134(1):29-38.

30. Benamouzig R, Deyra J, Martin A, Girard B, Jullian E, Piednoir B, Couturier D, Coste T, Little J, Chaussade S: Daily soluble aspirin and prevention of colorectal adenoma recurrence: one-year results of the APACC trial. Gastroenterology 2003, 125(2):328-336.

31. Burn J, Bishop DT, Mecklin JP, Macrae F, Moslein G, Olschwang S, Bisgaard ML, Ramesar R, Eccles D, Maher ER, et al: Effect of aspirin or resistant starch on colorectal neoplasia in the Lynch syndrome. The New England journal of medicine 2008, 359(24):2567-2578.

32. Burn J, Chapman PD, Bishop DT: Results of the CAPP1 study: aspirin and resistant starch are beneficial in familial adenomatous polyposis. Fam Cancer 2003, 2:42-45

33. Cook NR, Lee IM, Gaziano JM, Gordon D, Ridker PM, Manson JE, Hennekens $\mathrm{CH}$, Buring JE: Low-dose aspirin in the primary prevention of cancer: the Women's Health Study: a randomized controlled trial. JAMA : the journal of the American Medical Association 2005, 294(1):47-55.

34. Gann PH, Manson JE, Glynn RJ, Buring JE, Hennekens CH: Low-dose aspirin and incidence of colorectal tumors in a randomized trial. Journal of the National Cancer Institute 1993, 85:1220-1224.

35. Farrell B, Godwin J, Richards S, Warlow C: The United Kingdom transient ischaemic attack (UK-TIA) aspirin trial: final results. Journal of neurology, neurosurgery, and psychiatry 1991, 54(12):1044-1054.

36. Peto R, Gray R, Collins R, Wheatley K, Hennekens C, Jamrozik K, Warlow C, Hafner B, Thompson E, Norton S, et al: Randomised trial of prophylactic daily aspirin in British male doctors. Br Med J (Clin Res Ed) 1988, 296(6618):313-316.

37. Flossmann E, Rothwell PM: Effect of aspirin on long-term risk of colorectal cancer: consistent evidence from randomised and observational studies. Lancet 2007, 369(9573):1603-1613.

38. Chan AT, Arber N, Burn J, Chia WK, Elwood P, Hull MA, Logan RF, Rothwell PM, Schror K, Baron JA: Aspirin in the chemoprevention of colorectal neoplasia: an overview. Cancer Prev Res (Phila) 2012, 5(2):164-178.

39. Patrono C, Patrignani P, Garcia Rodriguez LA: Cyclooxygenase-selective inhibition of prostanoid formation: transducing biochemical selectivity into clinical read-outs. The Journal of clinical investigation 2001, 108(1):7-13.

40. Gupta RA, DuBois RN: Translational studies on Cox-2 inhibitors in the prevention and treatment of colon cancer. Annals of the New York Academy of Sciences 2000, 910:196-204, discussion 204-196.

41. Dannenberg AJ, Zakim D: Chemoprevention of colorectal cancer through inhibition of cyclooxygenase-2. Seminars in oncology 1999, 26(5):499-504.

42. Schror K: Acetylsalicyclic acid. 2009, Weinheim, Germany: WILEY-VCH Verlag $\mathrm{GmbH} \&$ Co. KGaA.

43. Ruschoff J, Dietmaier W, Bocker T, Wallinger S, Kullmann F, Beham A, Hofstadter F: Molecular cancer disposition diagnosis exemplified by colorectal carcinoma. What is the contribution of pathology? Der Pathologe 1998, 19(4):269-278.

44. Babbar N, Gerner EW, Casero RA Jr: Induction of spermidine/spermine N1acetyltransferase (SSAT) by aspirin in Caco-2 colon cancer cells. The Biochemical journal 2006, 394(Pt 1):317-324.
45. Martinez ME, O'Brien TG, Fultz KE, Babbar N, Yerushalmi H, Qu N, Guo Y, Boorman D, Einspahr J, Alberts DS, et al: Pronounced reduction in adenoma recurrence associated with aspirin use and a polymorphism in the ornithine decarboxylase gene. Proceedings of the National Academy of Sciences of the United States of America 2003, 100(13):7859-7864.

46. Onsenal: EPAR summary for the public. [http://www.ema.europa.eu/docs/ en_GB/document_library/EPAR___Summary_for_the_public/human/000466/ WC500044631.pdf]

47. Giardiello FM, Yang WW, Hylind LM, Krush AJ, Petersen GM, Trimbath JD, Piantadosi S, Garrett E, Geiman DE, Hubbard W, et al: Primary chemoprevention of familial adenomatous polyposis with sulindac. The New England journal of medicine 2002, 346(14):1054-1059.

48. Giardiello FM, Hamilton SR, Krush AJ, Piantadosi S, Hylind LM, Celano P, Booker SV, Robinson CR, Offerhaus GJ: Treatment of colonic and rectal adenomas with sulindac in familial adenomatous polyposis. The New England journal of medicine 1993, 328(18):1313-1316.

49. Nugent KP, Farmer KC, Spigelman AD, Williams CB, Phillips RK: Randomized controlled trial of the effect of sulindac on duodenal and rectal polyposis and cell proliferation in patients with familial adenomatous polyposis. The British journal of surgery 1993, 80(12):1618-1619.

50. Labayle D, Fischer D, Vielh P, Drouhin F, Pariente A, Bories C, Duhamel O, Trousset M, Attali P: Sulindac causes regression of rectal polyps in familial adenomatous polyposis. Gastroenterology 1991, 101(3):635-639.

51. Steinbach G, Lynch PM, Phillips RK, Wallace MH, Hawk E, Gordon GB, Wakabayashi N, Saunders B, Shen Y, Fujimura T, et al: The effect of celecoxib, a cyclooxygenase-2 inhibitor, in familial adenomatous polyposis. The New England journal of medicine 2000, 342(26):1946-1952.

52. Arber N, Eagle CJ, Spicak J, Racz I, Dite P, Hajer J, Zavoral M, Lechuga MJ, Gerletti P, Tang J, et al: Celecoxib for the prevention of colorectal adenomatous polyps. The New England journal of medicine 2006, 355(9):885-895.

53. Iwama T, Akasu T, Utsunomiya J, Muto T: Does a selective cyclooxygenase-2 inhibitor (tiracoxib) induce clinically sufficient suppression of adenomas in patients with familial adenomatous polyposis? A randomized double-blind placebo-controlled clinical trial. International journal of clinical oncology 2006, 11(2):133-139.

54. Bertagnolli MM, Eagle CJ, Zauber AG, Redston M, Solomon SD, Kim K, Tang J, Rosenstein RB, Wittes J, Corle D, et al: Celecoxib for the prevention of sporadic colorectal adenomas. The New England journal of medicine 2006, 355(9):873-884

55. Arber N, Spicak J, Racz I, Zavoral M, Breazna A, Gerletti P, Lechuga MJ Collins N, Rosenstein RB, Eagle CJ, et al: Five-year analysis of the prevention of colorectal sporadic adenomatous polyps trial. The American journal of gastroenterology 2011, 106(6):1135-1146.

56. Vaish V, Piplani H, Rana C, Sanyal SN: Angiostatic Properties of Sulindac and Celecoxib in the Experimentally Induced Inflammatory Colorectal Cancer. Cell biochemistry and biophysics 2012.

57. Lee $\mathrm{Y}, \mathrm{Kim} \mathrm{H}$, Kim W, Yoon JH, Jeong SH, Jung Y: Colon-specific delivery of celecoxib is a potential strategy to improve toxicological and pharmacological properties of the selective Cox-2 inhibitor: implication in treatment of familiar adenomatous polyposis. Journal of drug targeting 2012, 20(6):524-534.

58. Rayman MP: The use of high-selenium yeast to raise selenium status: how does it measure up? The British journal of nutrition 2004, 92(4):557-573

59. Mehdi $Y$, Hornick JL, Istasse L, Dufrasne I: Selenium in the environment, metabolism and involvement in body functions. Molecules 2013, 18(3):3292-3311.

60. Bera S, De Rosa V, Rachidi W, Diamond AM: Does a role for selenium in DNA damage repair explain apparent controversies in its use in chemoprevention? Mutagenesis 2013, 28(2):127-134.

61. Sanmartin C, Plano D, Sharma AK, Palop JA: Selenium compounds, apoptosis and other types of cell death: an overview for cancer therapy. International journal of molecular sciences 2012, 13(8):9649-9672.

62. Clark LC, Combs GF, Turnbull BW, Slate EH, Chalker DK, Chow J, Davis LS, Glover RA, Graham GF, Gross EG, et al: Effects of selenium supplementation for cancer prevention in patients with carcinoma of the skin. A randomized controlled trial. Nutritional Prevention of Cancer Study Group. JAMA : the journal of the American Medical Association 1996, 276(24):1957-1963. 
63. Lippman SM, Klein EA, Goodman PJ, Lucia MS, Thompson IM, Ford LG, Parnes HL, Minasian LM, Gaziano JM, Hartline JA, et al: Effect of selenium and vitamin $\mathrm{E}$ on risk of prostate cancer and other cancers: the Selenium and Vitamin E Cancer Prevention Trial (SELECT). JAMA : the journal of the American Medical Association 2009, 301(1):39-51.

64. You WC, Brown LM, Zhang L, Li JY, Jin ML, Chang YS, Ma JL, Pan KF, Liu WD, Hu Y, et al: Randomized double-blind factorial trial of three treatments to reduce the prevalence of precancerous gastric lesions. Journal of the National Cancer Institute 2006, 98(14):974-983.

65. Meyer F, Galan P, Douville P, Bairati I, Kegle P, Bertrais S, Estaquio C, Hercberg S: Antioxidant vitamin and mineral supplementation and prostate cancer prevention in the SU.VI.MAX trial. International journal of cancer Journal international du cancer 2005, 116(2):182-186.

66. Bjelakovic G, Nikolova D, Simonetti RG, Gluud C: Antioxidant supplements for prevention of gastrointestinal cancers: a systematic review and meta-analysis. Lancet 2004, 364(9441):1219-1228.

67. Reid ME, Duffield-Lillico AJ, Sunga A, Fakih M, Alberts DS, Marshall JR: Selenium supplementation and colorectal adenomas: an analysis of the nutritional prevention of cancer trial. International journal of cancer Journal international du cancer 2006, 118(7):1777-1781.

68. Peters U, Chatterjee N, Church TR, Mayo C, Sturup S, Foster CB, Schatzkin A, Hayes RB: High serum selenium and reduced risk of advanced colorectal adenoma in a colorectal cancer early detection program. Cancer epidemiology, biomarkers \& prevention : a publication of the American Association for Cancer Research, cosponsored by the American Society of Preventive Oncology 2006, 15(2):315-320.

69. Bonelli L, Puntoni M, Gatteschi B, Massa P, Missale G, Munizzi F, Turbino L, Villanacci $V$, De Censi A, Bruzzi P: Antioxidant supplement and long-term reduction of recurrent adenomas of the large bowel. A double-blind randomized trial. Journal of gastroenterology 2012.

70. British National Formulary. [http://www.bnf.org]

71. Berridge MJ, Lipp P, Bootman MD: The versatility and universality of calcium signalling. Nature reviews Molecular cell biology 2000, 1(1):11-21.

72. Cruzalegui $\mathrm{FH}$, Bading $\mathrm{H}$ : Calcium-regulated protein kinase cascades and their transcription factor targets. Cellular and molecular life sciences: CMLS 2000, 57(3):402-410

73. Lamprecht SA, Lipkin M: Cellular mechanisms of calcium and vitamin D in the inhibition of colorectal carcinogenesis. Annals of the New York Academy of Sciences 2001, 952:73-87.

74. Lipkin M: Preclinical and early human studies of calcium and colon cancer prevention. Annals of the New York Academy of Sciences 1999, 889:120-127.

75. Kallay E, Bajna E, Wrba F, Kriwanek S, Peterlik M, Cross HS: Dietary calcium and growth modulation of human colon cancer cells: role of the extracellular calcium-sensing receptor. Cancer detection and prevention 2000, 24(2):127-136.

76. Kim KZ, Shin A, Kim J, Park JW, Park SC, Choi HS, Chang HJ, Kim DY, Oh JH: Association between CASR Polymorphisms, Calcium Intake, and Colorectal Cancer Risk. PloS one 2013, 8(3):e59628.

77. Thomas MG, Thomson JP, Williamson RC: Oral calcium inhibits rectal epithelial proliferation in familial adenomatous polyposis. The British journal of surgery 1993, 80(4):499-501.

78. Bonithon-Kopp C, Kronborg O, Giacosa A, Rath U, Faivre J: Calcium and fibre supplementation in prevention of colorectal adenoma recurrence: a randomised intervention trial. European Cancer Prevention Organisation Study Group. Lancet 2000, 356(9238):1300-1306.

79. Baron JA, Beach M, Mandel JS, van Stolk RU, Haile RW, Sandler RS, Rothstein R, Summers RW, Snover DC, Beck GJ, et al: Calcium supplements for the prevention of colorectal adenomas. Calcium Polyp Prevention Study Group. The New England journal of medicine 1999, 340(2):101-107.

80. Hofstad B, Almendingen $\mathrm{K}$, Vatn M, Andersen SN, Owen RW, Larsen S, Osnes M: Growth and recurrence of colorectal polyps: a double-blind 3year intervention with calcium and antioxidants. Digestion 1998, 59(2):148-156

81. Stegeman I, de Wijkerslooth TR, Stoop EM, van Leerdam ME, Dekker E, van Ballegooijen M, Kuipers EJ, Fockens P, Kraaijenhagen RA, Bossuyt PM: Colorectal cancer risk factors in the detection of advanced adenoma and colorectal cancer. Cancer epidemiology 2013, 37(3):278-283.

82. Bristow SM, Bolland MJ, Maclennan GS, Avenell A, Grey A, Gamble GD, Reid IR: Calcium supplements and cancer risk: a meta-analysis of randomised controlled trials. The British journal of nutrition 2013, 1-10.
83. Park SY, Murphy SP, Wilkens LR, Nomura AM, Henderson BE, Kolonel LN: Calcium and vitamin D intake and risk of colorectal cancer: the Multiethnic Cohort Study. American journal of epidemiology 2007, 165(7):784-793.

84. Park $Y$, Leitzmann MF, Subar AF, Hollenbeck A, Schatzkin A: Dairy food, calcium, and risk of cancer in the NIH-AARP Diet and Health Study. Archives of internal medicine 2009, 169(4):391-401.

85. Cho E, Smith-Warner SA, Spiegelman D, Beeson WL, van den Brandt PA, Colditz GA, Folsom AR, Fraser GE, Freudenheim JL, Giovannucci E, et al: Dairy foods, calcium, and colorectal cancer: a pooled analysis of 10 cohort studies. Journal of the National Cancer Institute 2004, 96(13):1015-1022.

86. Huncharek M, Muscat J, Kupelnick B: Colorectal cancer risk and dietary intake of calcium, vitamin D, and dairy products: a meta-analysis of 26,335 cases from 60 observational studies. Nutrition and cancer 2009, 61(1):47-69.

87. Lappe JM, Travers-Gustafson D, Davies KM, Recker RR, Heaney RP: Vitamin $D$ and calcium supplementation reduces cancer risk: results of a randomized trial. The American journal of clinical nutrition 2007, 85(6):1586-1591

88. Wactawski-Wende J, Kotchen JM, Anderson GL, Assaf AR, Brunner RL, O'Sullivan MJ, Margolis KL, Ockene JK, Phillips L, Pottern L, et al: Calcium plus vitamin D supplementation and the risk of colorectal cancer. The New England journal of medicine 2006, 354(7):684-696.

89. Flood A, Peters U, Chatterjee N, Lacey JV, Schairer C, Schatzkin A: Calcium from diet and supplements is associated with reduced risk of colorectal cancer in a prospective cohort of women. Cancer epidemiology, biomarkers \& prevention : a publication of the American Association for Cancer Research, cosponsored by the American Society of Preventive Oncology 2005, 14(1):126-132.

90. Scott JM: Folate and vitamin B12. The Proceedings of the Nutrition Society 1999, 58(2):441-448

91. World Health Organization (WHO): Guideline: Daily Iron and Folic Acid Supplementation in Pregnant Women. Geneva 2012.

92. Duthie SJ: Folate and cancer: how DNA damage, repair and methylation impact on colon carcinogenesis. Journal of inherited metabolic disease 2011, 34(1):101-109.

93. Choi SW, Mason JB: Folate and carcinogenesis: an integrated scheme. The Journal of nutrition 2000, 130(2):129-132.

94. Pufulete M, Abbadi RA, Arno M, Ewins M, Green C, Astarloa EA, Sanders T, Emery $P$ : The influence of folate supplementation on global gene expression in normal colonic mucosa of subjects with colorectal adenoma. Molecular nutrition \& food research 2013, 57(4):709-720.

95. Baron JA, Sandler RS, Haile RW, Mandel JS, Mott LA, Greenberg ER: Folate intake, alcohol consumption, cigarette smoking, and risk of colorectal adenomas. Journal of the National Cancer Institute 1998, 90(1):57-62

96. Giovannucci E, Stampfer MJ, Colditz GA, Rimm EB, Trichopoulos D, Rosner BA, Speizer FE, Willett WC: Folate, methionine, and alcohol intake and risk of colorectal adenoma. Journal of the National Cancer Institute 1993, 85(11):875-884.

97. Zhang SM, Cook NR, Albert CM, Gaziano JM, Buring JE, Manson JE: Effect of combined folic acid, vitamin B6, and vitamin B12 on cancer risk in women: a randomized trial. JAMA : the journal of the American Medical Association 2008, 300(17):2012-2021.

98. Jaszewski R, Misra S, Tobi M, Ullah N, Naumoff JA, Kucuk O, Levi E, Axelrod BN, Patel BB, Majumdar AP: Folic acid supplementation inhibits recurrence of colorectal adenomas: a randomized chemoprevention trial. World journal of gastroenterology: WJG 2008, 14(28):4492-4498.

99. Zhu S, Mason J, Shi Y, Hu Y, Li R, Wahg M, Zhou Y, Jin G, Xie Y, Wu G, et al: The effect of folic acid on the development of stomach and other gastrointestinal cancers. Chinese medical journal 2003, 116(1):15-19.

100. Cole BF, Baron JA, Sandler RS, Haile RW, Ahnen DJ, Bresalier RS, McKeownEyssen G, Summers RW, Rothstein Rl, Burke CA, et al: Folic acid for the prevention of colorectal adenomas: a randomized clinical trial. JAMA the journal of the American Medical Association 2007, 297(21):2351-2359.

101. Qin X, Cui Y, Shen L, Sun N, Zhang Y, Li J, Xu X, Wang B, Huo Y, Wang X: Folic acid supplementation and cancer risk: $A$ meta-analysis of randomized controlled trials. International journal of cancer Journal international du cancer 2013.

102. Food and Agriculture Organization (FAO), World Health Organization (WHO): Report of a Joint FAO/WHO Expert Consultation on Evaluation of 
Health and Nutritional Properties of Probiotics in Food Including Powder Milk with Live Lactic Acid Bacteria. (EN) Health and Nutritional Properties of Probiotics in Food including Powder Milk with Live Lactic Acid Bacteria. 2001.

103. Geier MS, Butler RN, Howarth GS: Probiotics, prebiotics and synbiotics: a role in chemoprevention for colorectal cancer? Cancer biology \& therapy 2006, 5(10):1265-1269.

104. Ma EL, Choi YJ, Choi J, Pothoulakis C, Rhee SH, Im E: The anticancer effect of probiotic Bacillus polyfermenticus on human colon cancer cells is mediated through ErbB2 and ErbB3 inhibition. International journal of cancer Journal international du cancer 2010, 127(4):780-790.

105. Wollowski I, Rechkemmer G, Pool-Zobel BL: Protective role of probiotics and prebiotics in colon cancer. The American journal of clinical nutrition 2001, 73(2 Suppl):451S-455S.

106. Rafter J, Bennett M, Caderni G, Clune Y, Hughes R, Karlsson PC, Klinder A, O'Riordan M, O'Sullivan GC, Pool-Zobel B, et al: Dietary synbiotics reduce cancer risk factors in polypectomized and colon cancer patients. The American journal of clinical nutrition 2007, 85(2):488-496.

107. Worthley DL, Le Leu RK, Whitehall VL, Conlon M, Christophersen C, Belobrajdic D, Mallitt KA, Hu Y, Irahara N, Ogino S, et al: A human, doubleblind, placebo-controlled, crossover trial of prebiotic, probiotic, and synbiotic supplementation: effects on luminal, inflammatory, epigenetic, and epithelial biomarkers of colorectal cancer. The American journal of clinical nutrition 2009, 90(3):578-586.

108. Uccello M, Malaguarnera G, Basile F, D'Agata V, Malaguarnera M, Bertino G, Vacante $M$, Drago F, Biondi A: Potential role of probiotics on colorectal cancer prevention. BMC surgery 2012, 12(Suppl 1):S35.

109. Grosso G, Bei R, Mistretta A, Marventano S, Calabrese G, Masuelli L, Giganti MG, Modesti A, Galvano F, Gazzolo D: Effects of Vitamin C on health: a review of evidence. Frontiers in bioscience 2013, 18:1017-29.

110. Vitale DC, Piazza C, Melilli B, Drago F, Salomone S: Isoflavones: estrogenic activity, biological effect and bioavailability. European journal of drug metabolism and pharmacokinetics 2013, 38(1):15-25.

111. Li Volti G, Salomone S, Sorrenti V, Mangiameli A, Urso V, Siarkos I, Galvano F, Salamone F: Effect of silibinin on endothelial dysfunction and ADMA levels in obese diabetic mice. Cardiovascular diabetology 2011, 10:62

112. Grosso G, Galvano F, Mistretta A, Marventano S, Nolfo F, Calabrese G, Buscemi S, Drago F, Veronesi U, Scuderi A: Red orange: experimental models and epidemiological evidence of its benefits on human health. Oxidative medicine and cellular longevity 2013, 2013:157240.

113. Steiner M: Influence of vitamin E on platelet function in humans. Journal of the American College of Nutrition 1991, 10(5):466-473.

114. Kulie T, Groff A, Redmer J, Hounshell J, Schrager S: Vitamin D: an evidencebased review. Journal of the American Board of Family Medicine: JABFM 2009, 22(6):698-706.

115. Cranney A, Weiler HA, O'Donnell S, Puil L: Summary of evidence-based review on vitamin $D$ efficacy and safety in relation to bone health. The American journal of clinical nutrition 2008, 88(2):5135-519S.

116. Osborne JE, Hutchinson PE: Vitamin D and systemic cancer: is this relevant to malignant melanoma? The British journal of dermatology 2002, 147(2):197-213.

117. Greenberg ER, Baron JA, Tosteson TD, Freeman DH, Beck GJ, Bond JH, Colacchio TA, Coller JA, Frankl HD, Haile RW, et al: A clinical trial of antioxidant vitamins to prevent colorectal adenoma. Polyp Prevention Study Group. The New England journal of medicine 1994, 331(3):141-147.

118. McKeown-Eyssen G, Holloway C, Jazmaji V, Bright-See E, Dion P, Bruce WR: $A$ randomized trial of vitamins $C$ and $E$ in the prevention of recurrence of colorectal polyps. Cancer research 1988, 48(16):4701-4705.

119. Ponz de Leon M, Roncucci L: Chemoprevention of colorectal tumors: role of lactulose and of other agents. Scandinavian journal of gastroenterology Supplement 1997, 222:72-75.

120. Roncucci L, Di Donato P, Carati L, Ferrari A, Perini M, Bertoni G, Bedogni G, Paris B, Svanoni F, Girola M, et al: Antioxidant vitamins or lactulose for the prevention of the recurrence of colorectal adenomas. Colorectal Cancer Study Group of the University of Modena and the Health Care District 16. Diseases of the colon and rectum 1993, 36(3):227-234.

121. MacLennan R, Macrae F, Bain C, Battistutta D, Chapuis P, Gratten H, Lambert J, Newland RC, Ngu M, Russell A, et al: Randomized trial of intake of fat, fiber, and beta carotene to prevent colorectal adenomas. Journal of the National Cancer Institute 1995, 87(23):1760-1766.
122. Bjelakovic G, Nikolova D, Simonetti RG, Gluud C: Antioxidant supplements for preventing gastrointestinal cancers. Cochrane Database Syst Rev 2008, 3: CD004183.

123. Lin J, Cook NR, Albert C, Zaharris E, Gaziano JM, Van Denburgh M, Buring JE, Manson JE: Vitamins $\mathrm{C}$ and $\mathrm{E}$ and beta carotene supplementation and cancer risk: a randomized controlled trial. Journal of the National Cancer Institute 2009, 101(1):14-23.

124. Lee IM, Cook NR, Gaziano JM, Gordon D, Ridker PM, Manson JE, Hennekens $\mathrm{CH}$, Buring JE: Vitamin $\mathrm{E}$ in the primary prevention of cardiovascular disease and cancer: the Women's Health Study: a randomized controlled trial. JAMA : the journal of the American Medical Association 2005, 294(1):56-65.

125. Lonn E, Bosch J, Yusuf S, Sheridan P, Pogue J, Arnold JM, Ross C, Arnold A, Sleight $P$, Probstfield J, et al: Effects of long-term vitamin $E$ supplementation on cardiovascular events and cancer: a randomized controlled trial. JAMA : the journal of the American Medical Association 2005, 293(11):1338-1347.

126. Goodman GE, Thornquist MD, Balmes J, Cullen MR, Meyskens FL Jr, Omenn GS, Valanis B, Williams JH Jr: The Beta-Carotene and Retinol Efficacy Trial: incidence of lung cancer and cardiovascular disease mortality during 6-year follow-up after stopping beta-carotene and retinol supplements. Journal of the National Cancer Institute 2004, 96(23):1743-1750.

127. Hercberg S, Galan P, Preziosi P, Bertrais S, Mennen L, Malvy D, Roussel AM, Favier A, Briancon S: The SU.VI.MAX Study: a randomized, placebocontrolled trial of the health effects of antioxidant vitamins and minerals. Archives of internal medicine 2004, 164(21):2335-2342.

128. Malila N, Virtamo J, Virtanen M, Albanes D, Tangrea JA, Huttunen JK: The effect of alpha-tocopherol and beta-carotene supplementation on colorectal adenomas in middle-aged male smokers. Cancer epidemiology, biomarkers \& prevention : a publication of the American Association for Cancer Research, cosponsored by the American Society of Preventive Oncology 1999, 8(6):489-493.

129. Virtamo J, Pietinen $P$, Huttunen JK, Korhonen P, Malila N, Virtanen MJ, Albanes D, Taylor PR, Albert P: Incidence of cancer and mortality following alpha-tocopherol and beta-carotene supplementation: a postintervention follow-up. JAMA : the journal of the American Medical Association 2003, 290(4):476-485.

130. Duffield-Lillico AJ, Reid ME, Turnbull BW, Combs GF, Slate EH, Fischbach LA, Marshall JR, Clark LC: Baseline characteristics and the effect of selenium supplementation on cancer incidence in a randomized clinical trial: a summary report of the Nutritional Prevention of Cancer Trial. Cancer epidemiology, biomarkers \& prevention : a publication of the American Association for Cancer Research, cosponsored by the American Society of Preventive Oncology 2002, 11(7):630-639.

131. Hennekens CH, Buring JE, Manson JE, Stampfer M, Rosner B, Cook NR, Belanger C, LaMotte F, Gaziano JM, Ridker PM, et al: Lack of effect of longterm supplementation with beta carotene on the incidence of malignant neoplasms and cardiovascular disease. The New England journal of medicine 1996, 334(18):1145-1149.

doi:10.1186/1471-2482-13-S2-S16

Cite this article as: Nolfo et al:: Pharmacological and dietary prevention for colorectal cancer. BMC Surgery 2013 13(Suppl 2):S16.

\section{Submit your next manuscript to BioMed Central and take full advantage of:}

- Convenient online submission

- Thorough peer review

- No space constraints or color figure charges

- Immediate publication on acceptance

- Inclusion in PubMed, CAS, Scopus and Google Scholar

- Research which is freely available for redistribution 